RECYT

Year 23 / No 36 / 2021 / 78-83

\title{
Chemical constituents and bactericidal and fungicide potential of the essential oil of Pimenta dioica Lindl against pathogenic microorganisms
}

\section{Componentes químicos y potencial bactericida y fungicida del aceite esencial de Pimenta dioica Lindl contra microorganismos patógenos}

\author{
Gustavo O. Everton* , Ana Patrícia M. Pereira, Nilton S. C. Mafra, Paulo S. Santos Júnior, \\ Thércia G. Martins, Paulo V. S. Rosa, Paulo R.B. Gomes, Nestor E. Mendes Filho, V.E. Mouchrek Filho \\ Laboratório de Pesquisa e Aplicação de Óleos Essenciais (LOEPAV/UFMA). Universidade Federal do Maranhão (UFMA). Brasil. \\ *E-mail: gustavooliveiraeverton@gmail.com
}

Abstract

Received: 24/12/2020; Approved: 28/07/2021

\begin{abstract}
This study evaluated the chemical profile and antimicrobial activity of essential oil (EO) of $P$. dioica. The EOs were extracted by hydrodistillation and chemically characterized by gas chromatography coupled to mass spectrometry (GC/MS). The total phenolics were quantified by the Folin Ciocalteu method. For the antimicrobial assay, the Disc Diffusion and Broth Dilution method were applied to obtain the minimum inhibitory concentration and minimum bactericidal concentration. The main constituent of the EO was eugenol. The EO showed bactericidal activity against E. coli, S. aureus, P. aeruginosa, Salmonella sp., B. cereus, P. mirabilis, K. pneumoniae, S. sonnei, C. albicans, Fusarium $s p$., Penicillium $s p$. and Aspergilus $s p$. The results obtained are encouraged by the potential use of the EO studied in the control and combat of pathogenic microorganisms
\end{abstract}

Keywords: Antimicrobial; Essential oil; Pimenta.

\section{Resumen}

Este estudio evaluó el perfil químico y la actividad antimicrobiana del aceite esencial (AE) de $P$. dioica. Los AE fueron extraídos por hidrodestilación y caracterizados químicamente por cromatografía de gases acoplados a espectrometría de masas (GC/MS). Los fenólicos totales fueron cuantificados por el método Folin-Ciocalteu. Para el ensayo antimicrobiano, se aplicó el método de difusión de discos y dilución de caldo para obtener la concentración inhibitoria mínima y la concentración bactericida mínima. El componente principal de la AE fue el eugenol. La AE mostró actividad bactericida contra E. coli, S. aureus, P. aeruginosa, Salmonella sp., B. cereus, P. mirabilis, $K$. pneumoniae, S. sonnei, C. albicans, Fusarium sp., Penicillium sp. y Aspergilus $s p$. Los resultados obtenidos son estimulados por el uso potencial de la AE estudiada en el control y combate de microorganismos patógenos.

Palabras clave: Antimicrobiana; Aceite esencial; Pimenta.

\section{Introduction}

Plants are considered one of the main natural resources for medicinal use, due to their biological potential, either by the action of deadly diseases or diseases that affect living beings; therefore, and according to the World Health Organization, almost $80 \%$ of the population in developing countries uses them directly or indirectly for their basic health needs; either because of the cultural tradition or because of the absence of other options, due to the high cost of traditional medicines for this population (Bermúdez et al., 2005; Alitonou et al., 2012; Duarte et al., 2020).

Multidisciplinary efforts have also led to an increase in the number of studies in order to obtain greater knowledge about a medicinal plant (Duarte et al., 2020).) The study of substances extracted from plants has proved indispensable over time; either because of the great biological diversity in Brazil or because of the potential of this extraction. Thus, essential oils represent a viable alternative in several studies involving substances of plant origin (Gomes et al., 2020).

Specific analyses are necessary around the validation process, which include the chemical composition and proof of microbial pharmacological activity that ensure the quality of raw materials of plant origin (Gomes et al., 2020). The toxic potential of essential oils (EOs) and their compounds can significantly vary according to intrinsic 
and extrinsic factors (Kim et al., 2016).

The chemical composition of the EOs considerably contributes to the determination of the pharmacological potential attributed to plant species. In the case of EOs, it is regularly recommended to use the mass spectrum-coupled gas chromatography system (GC/MS) in order to identify substances derived from secondary metabolism (Mirzahosseini et al., 2017; Howyzeh et al., 2018). EO extracted from medicinal plants have been widely used successfully in research focused on epidemiological control (Mirzahosseini et al., 2017).

The Pimenta dioica (Lindl.) is a perennial tropical species of trees belonging to the family Myrtaceae. Known for its characteristic aroma, therapeutic and culinary qualities that resemble the aroma and flavor of clove and nutmeg (Dexheimer et al., 2017). This plant is known as Jamaica pepper, and its leaves or seeds powder are broadly used in traditional medicine for the treatment of flatulence, diarrhea, neuralgia, rheumatism, and digestive problems (Rao et al., 2012). In addition, it is valued for its secondary metabolites, such as EO with compositions and resin oil, which is highly used in the food, perfumery and cosmetic products industry (Martinez-Velazquez et al., 2011).

To date, there are few publications in relation to compositions and characterization of the EO of $P$. dioca (Martinez-Velazquez et al.; Padmakumari et al., 2011; Rao et al., 2012). Thus, the present work reports the chemical profile and antimicrobial potential of EO $P$. dioica.

\section{Methodology}

\section{Essential oil}

For extraction of the EO, the hydrodistillation technique was used with a glass Clevenger extractor coupled to a round-bottomed balloon packed in an electric blanket as a heat generating source. $90 \mathrm{~g}$ of the dried leaves of $P$. dioica were used, adding distilled water (1:10). Hydrodistillation was conducted at $100{ }^{\circ} \mathrm{C}$ for $3 \mathrm{~h}$ collecting the extracted EO. Each EO was dried by percolation with anhydrous sodium sulfate $\left(\mathrm{Na}_{2} \mathrm{SO}_{4}\right)$ and centrifugate. These operations were carried out in triplicates and samples stored in amber glass ampoules under $4{ }^{\circ} \mathrm{C}$ cooling. Subsequently, the analyses were submitted.

\section{Chemical constituents}

The spectra in the infrared region were obtained in the IR PRESTIGE-21 model equipment and were recorded in the $4000-400 \mathrm{~cm}^{-1}$ region. All tablets were prepared by using anhydrous potassium bromide $(\mathrm{KBr})$.

The EO constituents were identified by gas chromatography coupled to mass spectrometry (GC-MS). The the analysis conditions were as follows: Method: Adams. $\mathrm{M}$; Injected volume: $0.3 \mu \mathrm{L}$; Column: Capillary HP-5MS (5\% diphenyl, 95\% dimethyl polysiloxane ) (Equivalent DB-5MS or CP-Sil 8CB LB/MS), in dimensions (30 m x $0.25 \mathrm{~mm}$ x $0.25 \mu \mathrm{m})$; Drag gas : He (99.9995); $1.0 \mathrm{~mL} /$ min; Injector : $280^{\circ} \mathrm{C}$, Split mode (1:10); Oven: $40 \mathrm{oC}$ (5.0 min.) up to $240{ }^{\circ} \mathrm{C}$ at a rate of $4 \mathrm{oC} \cdot \mathrm{min}^{-1}$, from 240 $\mathrm{oC}$ to $300 \mathrm{oC}(7.5 \mathrm{~min})$ at a rate of $8 \mathrm{oC} \cdot \mathrm{min}^{-1}$; $\mathrm{tT}=60.0$ min; Detector: EM1; EI (70 eV); Scan mode $(0.5 \mathrm{sec} /$ scan); Mass range: 40 - 500 daltons (one); Line transfer: 280 oC.; Filament: off 0.0 to 4.0 min; Linear quadrupole mass spectrometer. The AMDIS (Automated Mass spectral Deconvolution Mass \& Identification System) program was used to identify the compounds in the sample.

\section{Total phenolics}

The determination of total phenolic EO phenolic compounds was performed with adaptation of the FolinCiocalteu (Waterhouse, 2002). $5 \mathrm{mg}$ of the essential oil diluted in $1 \mathrm{~mL}$ of ethanol was used. To this solution $3 \mathrm{~mL}$ of distilled water was added, $500 \mu \mathrm{L}$ of Folin-Ciocalteu reagent and $2.0 \mathrm{~mL}$ of sodium carbonate at $20 \%$. The solution formed was taken to the water bath at $50{ }^{\circ} \mathrm{C}$ for 5 min, removed and left to cool; and then, the reading was performed in a manual spectrophotometer, in a length of $760 \mathrm{~nm}$. The readings were performed in a spectrophotometer at $760 \mathrm{~nm}$, and the standard curve expressed in $\mathrm{mg}$ of tannic acid (EAT).

\section{Standardization of microbial inoculum for sensitivity tests}

Four strains of bacteria were used: Escherichia coli (ATCC 25922) and Staphylococcus aureus (ATCC 25923), Pseudomonas aeruginosa (ATCC 15442), Bacillus cereus (ATCC 14579), Proteus mirabilis (ATCC 29906), Klebsiella pneumoniae (ATCC 700603), Shigella sonnei (ATCC 25931) and Salmonella sp. (ATCC 700623). The fungi used were: Penicillium sp. (ATCC 38498), Aspergillus sp. (ATCC 201291), Fusarium sp. (ATCC 60289), Candida albicans (ATCC 10231). These were previously identified and confirmed by biochemical tests. Pure microbial cultures maintained in TSA Agar were peaked for brain and Heart Infusion Broth (HIB) and incubated at $35^{\circ} \mathrm{C}$ until they reached exponential growth phase (4-6 h). After this period, the cultures had their cell density adjusted in $0.85 \%$ sterile saline solution, in order to obtain turbidity comparable to that of the standard McFarland solution 0.5, which results in a microbial suspension containing approximately $1.5 \times 10^{8} \mathrm{CFU} \mathrm{mL}^{-1}$, according to (CLSI, 2020).

\section{Disk Diffusion Method (DDM)}

The Disc Diffusion technique was performed according to CLSI (CLSI, 2020) and, which standardizes the sensitivity tests of antimicrobials by disc-diffusion. First, the plates were prepared with the Mueller Hinton Agar (MHA) and Sabourad Dextrose Agar (SDA) culture medium after its solidification was distributed to the microbial suspension on the surface of the agar and left at room temperature for $30 \mathrm{~min}$. Soon after the discs containing $50 \mu \mathrm{L}$ of EOs and discs with defined concentrations of antibiotics, 
Gentamicin (GEN, $30 \mu \mathrm{g}$ ) for bacteria and Ketoconazole (CET, $50 \mu \mathrm{g}$ ) for fungi. Using sterile tweezers, the discs were distributed on the surface of the agar. The plates were incubated in a bacteriological greenhouse at $35^{\circ} \mathrm{C}$ for 24 hours and $25^{\circ} \mathrm{C}$ for 24 hours. The diameters of the inhibition halos were measured, including the diameter of the disc. These trials were done in triplicate. The values of the inhibition halos were the mean measurements of the three results. Tests performed in triplicate.

\section{Minimum Inhibitory Concentration (MIC) and Minimum Bactericidal Concentration (MBC)}

The Minimum Inhibitory Concentration (MIC) assay was performed by using the broth dilution technique, proposed by CLSI (CLSI, 2020) and by the methodology described by Arendrup et al. (2012). First, 2\% solutions were prepared by using dimethylsufoxide (DMSO) at $2 \%$, and serial dilutions were prepared in $\mathrm{MH}$ Broth, resulting in concentrations of 10 to $1000 \mu \mathrm{g} \mathrm{mL}^{-1}$. Microbial suspension containing $1.5 \times 10^{8} \mathrm{CFU} \mathrm{mL}^{-1}$ of the strains was added to each concentration. The tubes were incubated at $35{ }^{\circ} \mathrm{C}$ for $24 \mathrm{~h}$. Sterility and growth controls were performed for the assay. After the incubation period, the MIC of the EO was verified, being defined as the lowest concentration that visibly inhibited bacterial growth (absence of visible cloudiness). Tests performed in triplicate.

For the Minimum Bactericidal (MBC) e Fungicidal Concentration (MFC) assay, an aliquot of $100 \mu \mathrm{L}$ of the dilutions from $\mathrm{MH}$ broth that visibly inhibited microbial growth was used. The aliquots were inoculated in Mueller Hinton Agar (MHA) for bacteria e Sabourad Dextrose Agar (SDA) for fungi with subsequent incubation at $35^{\circ} \mathrm{C}$ during $24 \mathrm{~h}$ e $25^{\circ} \mathrm{C}$ for $24 \mathrm{~h}$, respectively. The MBC e MFC was determined as the lowest dose that visually, in the MIC assay, showed growth inhibition and that in the culture in $\mathrm{AMH}$ also did not present bacterial growth.

\section{Results and Discussion}

Table 1 presents the chemical constituents identified in the EO of $P$. dioica L, with eugenol being the majority constituent with $85.673 \%$ of the total composition of the EO. Seven constituents were identified in the EO, all belonging to the class of monoterpenes.

Table 1: EO chemical constituents.

\begin{tabular}{|c|c|c|c|}
\hline Order & RT (min) & Constituent & \% Area \\
\hline 1 & 8,772 & Octenol & 1,186 \\
\hline 2 & 9,164 & Myrcene & 2,762 \\
\hline 3 & 10,488 & Limonene & 1,730 \\
\hline 4 & 13,251 & Linalool & 0,884 \\
\hline 5 & 16,122 & Terpineol & 0,973 \\
\hline 6 & 19,026 & Chavicol & 6,792 \\
\hline 7 & 22,755 & Eugenol & 85,673 \\
\hline
\end{tabular}

Regarding the chemical profile, similar results were observed by Stewart et al. (2016) when verifying the chromatographic analyses performed by GC-MS of $P$. dioica EO, and observed eugenol $(61.36 \%)$ as majority constriction followed by $\beta$-caryophylenne (4.58\%), $\alpha$-humulene (1.90\%), 1.8-cineol (1.89\%), and other components in lower concentrations. Monteiro et al. (2015) analyzed the EO of $P$. dioica fruits, and also reported eugenol (76.98\%) as the majority component, followed by 5 -Idanol (5.88\%) and limonen $(4.09 \%)$.

The results also corroborate the study conducted by Oliveira (2017) and also observed the presence of eugenol (44.9\%) P. dioica EO, followed by $\beta$-pineno (21.0\%), limonen (10.1\%) and chavicol (7.5\%). Faria et al. (2017) also analyzed by CG/MS the EO of $P$. dioica and eugenol $(60.8 \%)$ was the majority constituent of the Constitution of the EO, followed by myrcene (19.3\%), limonen (6.48\%), and chavicol $(4.78 \%)$ constituents at lower concentrations. Panawala et al. (2016) verified, in their study, the chemical composition of the EO of the leaves of $P$. dioica, dectify 12 chemical compounds through GC-MS, comprising 97\% of the total composition. Eugenol $(85.33 \pm 2.0 \%)$ was the major component of EO, followed by $\beta$-caryophile $(4.36 \pm 0.3 \%)$ and cineol $(4.19 \% \pm 0.3 \%)$, linalool $(0.83 \pm$ $0.11 \%), \alpha$-humuleno $(0.76 \pm 0.12 \%)$.

Analyzing the EO of the fruits of $P$. dioica, Lorenzo-Leal et al. (2018) evaluated the chemical composition of the EO of $P$. dioica dried fruits, using the CG-MS technique, and identified 5 chemical components. The main compounds detected were eugenol (89.55\%), $\alpha$-terpinol (2.04\%) and carioene oxide (1.48\%). However, different percentages of eugenol were found by some authors such as Mathew (2017) who observed in their analyses that EO of $P$. dioica may contain 80 to $87 \%$ of eugenol and Amma et al. (2013) who found the percentage of $68.4 \%$ of eugenol.

Voris et al. (2017) observed chromatographic analyses performed by the CG-MS technique of $P$. dioica EO, identified 7 chemical components, methyl-eugenol (55.26\%), eugenol (35.72\%), $\beta$ - farnecene (4.54\%) and $\beta$-pineno $(2.94 \%)$. The major component of EO was methyl-eugenol, so this result differs from that found in this study. According to Figueiredo et al. (2008), this variation in concentration can be explained among other factors, by soil composition, temperature and climate of cultivation, climatic differences and sun exposure. The chemical composition of the EO of a plant is determined by genetic and physiological factors, but it may undergo significant variations as a result of environmental factors such as climate and the cultivation place (OLIVEIRA et al., 2009). According to Scherer et al. (2009), this variation can directly influence the functional properties of EOs, such as antioxidant and antimicrobial activity. 


\section{Total phenolics}

In the Folin-Ciocalteu assay, the total phenolic content of $350.14 \pm 5.20 \mathrm{mg}^{\mathrm{EAT}} \mathrm{g}^{-1}$ present in the EO of $P$. dioica was quantified.

For the Folin-Ciocalteu trial, using the same methodology Panawala et al. (2016), compared the total antioxidant capacity, the total content of phenolic and flavonoids, according to different leaf positions of the leaves and parts of $P$. dioica. The total phenolics found were slightly similar to that of this study, with $267.53 \pm 5.03$ and $192.20 \pm 8.00$ mg GAE g ${ }^{-1}$ (mg gallic acid equivalent), in the shoots and immature leaves of the plant, respectively.

In other products obtained from $P$. dioica, Manorama (2016) found higher phenolic content in the stem of the aqueous extract, compared to other extracts. The determination that resulted in $16.31 \pm 0.5 \mathrm{GAE} \mathrm{g}^{-1}$ sample. Kumar et al. (2010), revealed the total phenolic content of $P$. dioica aqueous extract in $\mathrm{mg} / \mathrm{g}$ of equivalent biting acid, resulting in $0.0524 \mathrm{mg} \mathrm{g}^{-1}$, a value lower than that of this research, further inferring its potential.

Phenolic compounds constitute a large part of the vegetables and have several physiological and morphological properties, mainly linked to antioxidant action in plants (Puupponen-Pimiä et al., 2001; Manach et al., 2005). According to the results of the present study, the EO of P. dioica exhibited a significant value of the compound.

\section{Antimicrobial potential}

Table 2 presents the results obtained for antimicrobial activity for EO action.

Table 2: Diameter of inhibition halos (mm), MIC ( $\mu \mathrm{g} \mathrm{mL-1)}$ and MBC ( $\mu \mathrm{g}$ $\mathrm{mL}-1)$ of EO.

\begin{tabular}{|c|c|c|c|c|c|c|}
\hline Microorganisms & $\begin{array}{c}\text { CET } \\
(50 \mu \mathrm{g})\end{array}$ & $\begin{array}{c}\text { GEN } \\
(30 \mu g)\end{array}$ & $\begin{array}{c}\text { DIH } \\
(\mathrm{mm})\end{array}$ & 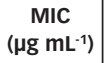 & $\begin{array}{c}M B C \\
\left(\mu g \mathrm{~mL}^{-1}\right)\end{array}$ & 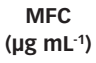 \\
\hline E. coli & - & 19 & $15 \pm 1,2$ & 100 & 370 & - \\
\hline S. aureus & - & 26 & $24 \pm 2,1$ & 50 & 200 & - \\
\hline$P$. aeruginosa & - & 13 & $10 \pm 1,5$ & 350 & 700 & - \\
\hline Salmonella sp. & - & 12 & $11 \pm 1,1$ & 220 & 450 & - \\
\hline B. cereus & - & 12 & $14 \pm 1,9$ & 400 & 800 & - \\
\hline P. mirabilis & - & 13 & $12 \pm 1,5$ & 450 & 870 & - \\
\hline K. pneumoniae & - & 21 & $17 \pm 1,7$ & 380 & 630 & - \\
\hline S. sonnei & - & 15 & $14 \pm 1,4$ & 400 & 690 & - \\
\hline C. albicans & 29 & - & $24 \pm 1,3$ & 400 & - & 620 \\
\hline Fusarium sp. & 28 & - & $25 \pm 1,1$ & 450 & - & 600 \\
\hline Penicillium sp. & 30 & - & $31 \pm 0,60$ & 330 & - & 500 \\
\hline Aspergilus $s p$. & 25 & - & $20 \pm 0,80$ & 520 & - & 850 \\
\hline
\end{tabular}

As observed in Table 2, P. dioica EO was tested against two groups of bacteria (gram-positive and gram-negative) and pathogenic fungi. The results demonstrated that the EO showed significant inhibition against the bacterial and fungal strains tested, presenting inhibition halos between
10 and $31 \mathrm{~mm}$. The best EO results for the bacteria studied were for $\mathrm{S}$. aureus and E. coli with MIC ranging from 50 to $100 \mu \mathrm{g} \mathrm{mL}^{-1}$ and MBC between 200 and $370 \mu \mathrm{g} \mathrm{mL}^{-1}$. For the other bacterial strains, antimicrobial activity also manifested with strongly inhibited MIC.

In a previous study by Lorenzo-Leal et al. (2019), on the antimicrobial action of $P$. dioica EO, described that the EO presented better activity on A. baumannii, $P$. aeruginosa, $S$. aureus, with MIC, ranging between 500 and $2000 \mu \mathrm{g} \mathrm{mL}^{-1}$. These results revealed the importance of this study, which obtained higher antimicrobial potential of pepper EO. In addition, the bacterial strain of $E$. coli used by Lorenzo-Leal et al. (2019) was resistant to the concentrations tested.

Oussalah et al., (2007), revealed the antibacterial potential of $P$. dioica EO against $E$. coli, Listeria monocytogenes, $S$. aureus and $S$. typhimurium, with MIC ranging between $0.1 \%$ and $0.2 \%$. When verifying the antimicrobial activity of spices on bacterial development Binatti et al., (2016), they found that the aqueous extract of allspice did not significantly inhibit the balms B. cereus, B. subtilis, S. aureus, S. Enteritidis, S. typhimurium, which exhibited inhibition halos between 6 and $8 \mathrm{~mm}$. Unlike the results found in this study that demonstrated inhibition of $11 \mathrm{~mm}$, $14 \mathrm{~mm}$ and $24 \mathrm{~mm}$ for Salmonella sp., B. cereus and $S$. aureus, respectively.

Regarding antifungal activity, $P$. dioica $\mathrm{EO}$ was able to inhibit the growth of all four fungal strains tested, especially Penicillium sp. which exhibited inhibition halo of 31 $\mathrm{mm}$, a value similar to that of the control (CET=30 mm). However, Martinelli et al. (2017), indicated antifungal action of $P$. dioica EO at a concentration of $0.25 \%$ on Penicillium sp.

Lowe et al. (2017), when analyzing the antifungal potential of ethyl acetate extract from $P$. dioica leaves, declared that it was more active to inhibit the growth of $C$. albicans, with MIC of $0.63 \mathrm{mg} / \mathrm{mL}$ and MFC of 1, $3 \mathrm{mg} /$ $\mathrm{mL}$ while in this study, and for this same fungus, the MIC and MFC values were 400 and $620 \mu \mathrm{g} \mathrm{mL}^{-1}$, respectively.

Another study reported that $P$. dioica EO promoted total inhibition of mycelial growth of Fusarium oxysporum f species. sp. lycopersici, Fusarium oxysporum f. sp. passiflorae, Fusarium subglutinans f. sp. ananas, Fusarium f. sp. vasinfectum and Fusarium oxysporum f. sp. cubense, at concentrations ranging from 86.67 and 97.78\% (Júnior, 2011).

In the study by Kim et al. (2016), the inhibition rates of EO of Allspice were $36.3,30.5$ and $0 \%$ against $A$. ochraceus, $A$. niger and $A$. parasiticus, respectively. In this study, Aspergillus sp. exhibited higher inhibition rate with MIC of $520 \mu \mathrm{g} \mathrm{mL}^{-1}$ and MFC of $850 \mu \mathrm{g} \mathrm{mL}^{-1}$.

The chemical composition of essential oils is linked to their antimicrobial activity. Thus, eugenol is a component that presents proven antimicrobial activities (Burt, 2004) and it possibly was the cause of antimicrobial activity in 
this study. In a work by Devi et al. (2010), on the evaluation of eugenol antimicrobial activity, they observed antibacterial potential on $S$. typhi $(\mathrm{MIC}=0,0125 \%)$ during 1 hour of eugenol exposure.

The fungal activity of glycosidic derivatives of eugenol was presented by Orlandi et al., (2013), who described the synthesis of four eugenol derivatives, three of which demonstrated biological activity against several species of Candida. Therefore, and according to the literary data, this study demonstrated high antimicrobial potential, proving the bactericidal and fungicide effect of the essential oil of $P$. dioica.

\section{Conclusions}

The essential oil presented eugenol as the major component, being attributed to it the antimicrobial potential observed, thus encouraging the application of this essential oil in the control and combat of pathogenic microorganisms tested.

\section{References}

1. Alitonou, G. A., Noudogbessi, J., Sessou, P., Tonouhewa, A., Avlessi, F., Menut, C., \& Sohounhloue, D. C. (2012). Chemical composition and biological activities of essential oils of Pimenta racemosa (Mill.) JW Moore. from Benin. Int J Biosci, 2(9), 1-12.

2. Amma, K. P., Rani, M. P., Sasidharan, I., \& Sreekumar, M. M. (2013). Comparative chemical composition and in vitro antioxidant activities of essential oil isolated from the leaves of Cinnamomum tamala and Pimenta dioica. Natural Product Research, 27(3), 290-294.

3. Arendrup, M. C., Cuenca-Estrella, M., Lass-Flörl, C., Hope, W., \& Eucast-Afst. (2012). EUCAST technical note on the EUCAST definitive document EDef 7.2: method for the determination of broth dilution minimum inhibitory concentrations of antifungal agents for yeasts EDef 7.2 (EUCAST-AFST). Clinical Microbiology and Infection, 18(7), E246-E247.

4. Bermúdez, A., Oliveira-Miranda, M. A., \& Velázquez, D. (2005). La investigación etnobotánica sobre plantas medicinales: una revisión de sus objetivos y enfoques actuales. Interciencia, 30(8), 453-459.

5. Binatti, T. T., Geromel, M. R., \& Fazio, M. L. S. (2016). Ação antimicrobiana de especiarias sobre o desenvolvimento bacteriano. Hig. alim., 105-108.

6. Burt, S. (2004). Essential oils: their antibacterial properties and potential applications in foods-a review. International journal of food microbiology, 94(3), 223253.

7. CLSI. Performance standards for antimicrobial susceptibility testing: CLSI M100 30th. Wayne, PA: Clinical and Laboratory Standards Institute 2020.

8. Dexheimer, G. M., \& Pozzobon, A. (2017). Atividade biológica de plantas da família Myrtaceae: revisão sistemática de artigos entre 1989 e 2015. Revista Cubana de Plantas Medicinales, 22(2).

9. Devi, K. P., Nisha, S. A., Sakthivel, R., \& Pandian, S. K. (2010). Eugenol (an essential oil of clove) acts as an antibacterial agent against Salmonella typhi by disrupting the cellular membrane. Journal of ethnopharmacology, 130(1), 107-115.

10. Duarte, L. S., Pereira, M. T. M., Pascoal, V. D. Á. B., \& Pascoal, A. C. R. F. (2020). Campomanesia genus-a literature review of nonvolatile secondary metabolites, phytochemistry, popular use, biological activities, and toxicology. Eclética Química Journal, 45(2), 12-22.

11. Faria, L. R., Pimenta, P. H., Oliveira, L. D. A. R., de Castro Peixoto, J., Ferri, P. H., \& de Paula, J. A. M. (2014). Structural organization and phytochemical analysis of Pimenta dioica (L.) (Myrtaceae) leaves collected from Gois State, Brazil. Journal of Medicinal Plants Research, 8(38), 1134-1147.

12. Figueiredo, A. C., Barroso, J. G., Pedro, L. G., \& Scheffer, J. J. (2008). Factors affecting secondary metabolite production in plants: volatile components and essential oils. Flavour and Fragrance journal, 23(4), 213-226.

13. Gomes, P. R. B., Oliveira, M. B., de Sousa, D. A., da Silva, J. C., Fernandes, R. P., Louzeiro, H. C., ... \& Fontenele, M. A. (2019). Larvicidal activity, molluscicide and toxicity of the essential oil of Citrus limon peels against, respectively, Aedes aegypti, Biomphalaria glabrata and Artemia salina. Eclética Química Journal, 44(4), 85-95.

14. Howyzeh, M. S., Noori, S. A. S., \& Shariati, v. (2018). Essential oil profiling of ajowan (Trachyspermum ammi) industrial medicinal plant. Industrial Crops and Products, 119, 255-259.

15. Júnior, B. (2011). Estudo químico e atividade antifúngica do óleo essencial dos frutos da Pimenta dioica Lindl. Dissertação De Mestrado - Programa De PósGraduação Em Quimica, 78p.

16. Kim, E., Oh, C. S., Koh, S. H., Kim, H. S., Kang, K. S., Park, P. S., ... \& Park, I. K. (2016). Antifungal activities after vaporization of ajowan (Trachyspermum ammi) and allspice (Pimenta dioica) essential oils and blends of their constituents against three Aspergillus species. Journal of Essential oil Research, 28(3), 252-259.

17. Kumar, B. H., Badarudin, A. N. J. U. M., \& Jose, A. (2010). $D P P H$ Radical scavenging activity and antibacterial activity of Pimenta dioica (L.) Merr. Oriental Journal of Chemistry, 26(4), 1501-1505.

18. Lorenzo-Leal, A. C., Palou, E., López-Malo, A., \& Bach, H. (2019). Antimicrobial, cytotoxic, and anti-inflammatory activities of Pimenta dioica and Rosmarinus officinalis essential oils. BioMed research international, 2019.

19. Lorenzo-Leal, A. C., Palou, E., \& López-Malo, A. (2018). Extraction, composition, and antibacterial effect of allspice (Pimenta dioica) essential oil applied in vapor phase. 116,000 120M, 82. 
20. Lowe, H. I., Daley, D. K., Lindo, J., Davis, C., Rainford, L., Hartley, S. A., ... \& Bahadoosingh, P. (2017). The antibacterial and antifungal analysis of crude extracts from the leaves and bark of Pimenta species found in Jamaica. Journal of Medicinal Plants Research, 11(38), 591-595.

21. Manach, C., Williamson, G., Morand, C., Scalbert, A., \& Rémésy, C. (2005). Bioavailability and bioefficacy of polyphenols in humans. I. Review of 97 bioavailability studies. The American journal of clinical nutrition, 81(1), 230S242S.

22. Manorama, S. S. (2015). Ethnobotanical, Phytochemical and in vitro antioxidant activity of medicinal plant Pimenta dioica (l.) Merr.(Myrtaceae) from Attappadi, Palakkad district, Kerala. Research in Pharmacy, 4(1).

23. Martinez-Velazquez, M., Castillo-Herrera, G. A., Rosario-Cruz, R., Flores-Fernandez, J. M., Lopez-Ramirez, J., Hernandez-Gutierrez, R., \& del Carmen Lugo-Cervantes, E. (2011). Acaricidal effect and chemical composition of essential oils extracted from Cuminum cyminum, Pimenta dioica and Ocimum basilicum against the cattle tick Rhipicephalus (Boophilus) microplus (Acari: Ixodidae). Parasitology Research, 108(2), 481-487.

24. Martinelli, L., Rosa, J. M., Ferreira, C. D. S. B., Nascimento, G. M. D. L., Freitas, M. S., Pizato, L. C., ... \& Granato, A. C. (2017). Antimicrobial activity and chemical constituents of essential oils and oleoresins extracted from eight pepper species. Ciência Rural, 47(5).

25. Mathew, A. (2017). Natural food flavors and colorants. Natural food flavors and colorants. (Ed. 2) 397.

26. Monteiro, O. S., Souza, A. G., Soledade, L. E. B., Queiroz, N., Souza, A. L., Mouchrek Filho, V. E., \& Vasconcelos, A. F. F. (2011). Chemical evaluation and thermal analysis of the essential oil from the fruits of the vegetable species Pimenta dioica Lindl. Journal of thermal analysis and calorimetry, 106(2), 595-600.

27. Mirzahosseini, S. M., Noori, S. A. S., Amanzadeh, Y., Javid, M. G., \& Howyzeh, M. S. (2017). Phytochemical assessment of some native ajowan (Therachyspermum ammi L.) ecotypes in Iran. Industrial Crops and Products, 105, 142-147.

28. Oliveira, F. S. (2017). Atividade antioxidante e antimicrobiana de óleos essenciais aplicados na preservação de lingüiça frescal de frango. Dissertação de Mestrado da Universidade Federal de Minas Gerais, 62p.

29. Oliveira, R. A. D., Reis, T. V., Sacramento, C. K. D., Duarte, L. P., \& Oliveira, F. F. D. (2009). Constituintes químicos voláteis de especiarias ricas em eugenol. Revista Brasileira de Farmacognosia, 19(3), 771-775.

30. Orlandi, E. P. (2013). A materialidade do gesto de interpretação e o discurso eletrônico. Formas de mobilidade no espaço e-urbano: sentido e materialidade digital. Campinas: Labeurb/Nudecri, 2, 1-15.

31. Oussalah, M., Caillet, S., Saucier, L., \& Lacroix, M. (2007). Inhibitory effects of selected plant essential oils on the growth of four pathogenic bacteria: E. coli O157: H7,
Salmonella typhimurium, Staphylococcus aureus and Listeria monocytogenes. Food control, 18(5), 414-420.

32. Padmakumari, K. P., Sasidharan, I., \& Sreekumar, M. M. (2011). Composition and antioxidant activity of essential oil of pimento (Pimenta dioica (L) Merr.) from Jamaica. Natural product research, 25(2), 152-160.

33. Panawala, P. B. C., Abeysinghe, D. C., \& Dharmadasa, R. M. (2016). Phytochemical distribution and bioactivity of different parts and leaf positions of Pimenta dioica (L.) Merr (Myrtaceae). World, 4(5), 143-146.

34. Puupponen-Pimiä, R., Nohynek, L., Meier, C., Kähkönen, M., Heinonen, M., Hopia, A., \& Oksman-Caldentey, K. M. (2001). Antimicrobial properties of phenolic compounds from berries. Journal of applied microbiology, 90(4), 494-507.

35. Rao, P. S., Navinchandra, S., \& Jayaveera, K. N. (2012). An important spice, Pimenta dioica (Linn.) Merill: A review. International Current Pharmaceutical Journal, 1(8), 221-225.

36. Scherer, R., Wagner, R., Duarte, M. C. T., \& Godoy, H. T. (2009). Composição e atividades antioxidante e antimicrobiana dos óleos essenciais de cravo-da-índia, citronela e palmarosa. Revista Brasileira de Plantas Medicinais, 11(4), 442-449.

37. Stewart, T. M. A., Lowe, H. I., \& Watson, C. T. (2016). Quantification and characterization of Pimenta dioica (Allspice) essential oil extracted via hydrodistillation, solvent and super critical fluid extraction methodologies. American Journal of Essential Oils and Natural Products, 4(3), 27-30.

38. Voris, D. G. D. R., Afonso, C. H., Almeida Filho, C. A., Fernandes, C. O., Brito, D. Q., Moraes, C. S., ... \& Avelar, K. E. (2017). Estudos etnofarmacológicos de óleos essenciais com atividade larvicida contra o mosquito Aedes aegypt. Semioses, 11(1), 86-94.

39. Waterhouse, A. L. (2002). Wine phenolics. Annals of the New York Academy of Sciences, 957(1), 21-36. 